\title{
CHARACTERISTICS OF SPECIALIZED MEDICAL CARE PERSONNEL PROVISION IN TRANSCARPATHIAN REGION, UKRAINE
}

\author{
Keretsman A. O., Melnichuk N. I.
}

\section{INTRODUCTION}

Human resources are the basis of the health care system. Providing a healthy lifestyle and well-being for people of all ages significantly depends on the human resources of the health care system (HCS), in particular their relevance to the needs of the population, as well as the acceptability and quality of the services they provide ${ }^{1}$. That is why the implementation of United Nations initiatives, international commitments in the framework of European integration processes significantly changes the health care system in Ukraine, which is reflected in Presidential Decree № 722/2019 “On Sustainable Development Goals of Ukraine until 2030"2 .The main goal of the reform is to provide all citizens equal access to high-quality medical services, which requires a balanced health-workforce policy and targeted actions for its implementation and realization. After the passing the Law of Ukraine (October 19, 2017) № 2168-VIII “On state financial guarantees of health care" 3 of funding and infrastructure of primary care based on the principle "money follows the patient", and from April 1, 2020, similar principles were applied to other types of medical care. All allocations of the state budget for public medical care services are accumulated in the National Health Service of Ukraine (NHSU) and are paid to health care institutions (HCI) for the result of their work, namely for medical services.

Thus, before changing the structure of the system, firstly it is needed to analyze its human resource. The implementation of the medical reform leads to corresponding changes in the structure of services and this influences the requirement for health-workforce, especially for specialized experts. Taking into account differences in the geographical distribution of health-workforce dentistry in Ukraine ${ }^{4}$ we think that the study of human resource potential of

1 Global strategy on human resources for health: workforce 2030. URL: https://www.who.int/hrh/resources/global_strategy_workforce2030_14_print.pdf?ua=1.

2 Указ Президента України від 30.09.2019 № 722/2019 «Про Цілі сталого розвитку України на період до 2030 року». URL: https://zakon.rada.gov.ua/laws/show/722/2019.

3 Закон України від 19.10.2017 № 2168-VIII «Про державні фінансові гарантії медичного обслуговування населення». URL: https://zakon.rada.gov.ua/laws/show/2168-19.

${ }^{4}$ Богдан Д., Бойко А., Василькова А. та ін. Кадрові ресурси системи охорони здоров'я в Україні. Ситуаційний аналіз. Проект USAID «Підтримка реформи охорони здоров’я» 
secondary care doctors at the regional level, particularly in the Transcarpathian region as one of the regions with low density of health workers and specific geographical locations of its territories is really needed.

Situational analysis of the characteristics and trends of staffing specialized medical care at the regional level is particularly relevant to determine the purpose and objectives of the study.

\section{Workforce risks}

Medical reform in 2020 is going through the following stages: by January 31, 2020, the autonomy and computerization of health care institutions (HCIs), which are mostly transformed into municipal non-profit enterprises (MNPEs), should be completed. By February 2020 - the list of medical services that will be provided free of charge to patients in hospitals had to be published; by April 2020 - the reorganized HCIs had to register in the electronic system eHealth, as well as enter into agreements with the NHSU; from April 1, 2020 - the start of new rules of medical care services for secondary (specialized) and tertiary (highly specialized) medical care. Specialized and highly specialized health care institutions do not receive a budget subvention anymore and are funded by the NHSU for the number of services provided under the Medical Guarantee Program (the so-called "money follows the patient" approach) ${ }^{5}$.

Also during the year, according to the Cabinet of Ministers of Ukraine, hospital districts with the formation of reference HCIs should be created. They will unite medical institutions that have received a license to serve the population of a certain area. It is also expected to implement the system of electronic medical records and electronic sick-leaves records.

So as a result of the health care reform in 2020 for the citizens is going to be a number of positive developments: the patient can choose the health care institution and a doctor to obtain free medical care (in case he/she has a direction from a family physician) on one's own, which removes the reference to the place of residence that forced the patient to go to the hospital at the place of residence, or to pay "charity" to the desired hospital. The first way of the access to free medical services on secondary level in the reformed medicine becomes the electronic direction got after "primary" doctor visit, and that doctor is family doctor, physician, pediatrician, with whom the Declaration is signed. The self-appeal to obtain free medical care will be

URL: https://www.umj.com.ua/article/138238/obgruntuvannya-kontseptsiyi-bezperervnogovdoskonalennya-natsionalnoyi-sistemi-ohoroni-zdorov-ya-ukrayini.

5 Устінов О.В. Реформування медичної галузі в Україні отримало законодавче забезпечення №4 (84) VII - VIII 2011 г. URL: https://www.umj.com.ua/article/ writer/ustinov-a-v. 
possible only in cases when the patient's condition is requiring emergency medical care, obstetrician-gynecologists help (including medical care during childbirth, including surgery), pediatricians, psychiatrist, narcologist emergency treatment and emergency delivery brigade (emergency) medical care. Dental care (except emergency cases), beauty treatments, massage are and will be paid.

Medical reform of tertiary care will proceed likewise, however, considering the complexity of those services and the corresponding features of the HCIs, some of which are members of the National Academy of medical Sciences there is going to function a special financial regulation, in particular, there will be pilot projects financing for the provision of medical services in private research institutions, also Unified State Information System of organ transplantation and tissues and stuff is going to be created.

The main effects on HCIs' work are: work on a modified funding model: they will work as non-profit type enterprises, and not as budget institutions. It provides their financial independence, which will be the basis of competitiveness between HCIs. This means hospitals are required to take care of involving patients and increasing quality of their services on their own, because more patients hospital helps, better funding it gets. But NHSU funding and autonomy do not mean that HCIs will not be able to receive funds from the governmental budget. Some programs on local or state budget funds may be used to cover specific expenses, but this funding will not be major and will not be considered as content any more. Local councils can help HCIs to save money and more effectively structure the expenses by exempting them from certain public services and taxes.

The reform implementation leads to changes in the services structure, which gives number of risks in the context of personnel (health-workforce) policy: will it satisfy new challenges and needs of the industry or will it provide qualified health care to the population. Both international and Ukrainian experts noted that studying son the dynamics of such changes seem to be really necessary recently ${ }^{6,7,8}$. In fact before for a long time in Ukraine, specialization of medical staff occurred at the stage of internship training after the state distribution, which took into account only actual needs of the institutions and not its dynamic changes in condition of

${ }^{6}$ Campbell, J., Buchan, J., Cometto, G., David, B., Dussault, G., Fogstad, H., ... \& Quain, E.E. Human resources for health and universal health coverage: fostering equity and effective coverage. Bulletin of the World Health Organization. 2013. № 91. C. 853-863.

${ }_{7}$ Conceptual framework for human resources for health / Global Health Workforce Alliance. URL: https://www.capacityproject.org/framework.

${ }^{8}$ Надутий К.О., Лехан В.М., Найда І.В. Обгрунтування концепції безперервного вдосконалення національної системи охорони здоров’я України. Український медичний часопис, 2019. URL: https://doi.org/10.32471/umj.1680-3051.129.138238. 
reforming. In addition, for the past ten years, there was spontaneous intraindustry migration of medical staff: the state distribution of specialists existed, but they were free to change their work on their own, that partially reflected trends of changes in the structure of services, physicians, pediatricians and some medical specialists became general practitioners and family doctors. At the same time there was also a reverse process when primary care physicians had a very narrow specialization ${ }^{9}$.

There is still a great risk of external lab our migration, including health workforce whose contributions to the staffing situation of other countries is significant. It is difficult to estimate the exact scale of external migration because the imitations of national statistical reports on human resources in the health care area of Ukraine ${ }^{10}$.

\section{The results and discussion}

The research methodology involved the use of complex methods: bibliosemantic, analytical and medical statistics.

Data of scientific literature, regulatory documents of Ukraine and the official WHO documents, Center for health statistics of the MOH of Ukraine and Transcarpathian regional medical information-analytical center (reporting forms 17, 20 and 47) were sources of information for this research.

The analysis of staff provision according to the level of medical care was done by using the data of Center of medical statistics of MOH of Ukraine and Transcarpathian regional medical information-analytical center (reporting forms 17, 20 and 47). Specialists were divided according to specialization into groups: therapeutic, surgical, obstetric, pediatric, diagnostic and others.

The research objective was to study the ratio of medical staff to the population of the Transcarpathian region (calculated per 10 thousand population), to analyze regional differences in staffing comparing to other parts of Ukraine, to study trends secondary care staffing resources in the dynamics 2014-2018.

At present time Ukraine has formed a powerful human resource of qualified professionals, however the lack of actual data on migration of health workers ${ }^{11}$ and the lack of a unified strategy of human resources ${ }^{12}$ planning still

9 Закон України «Про формування та розміщення державного замовлення на підготовку фахівців, наукових, науково-педагогічних і робітничих кадрів, підвищення кваліфікації та перепідготовку кадрів» зі змінами, внесеними згідно із Законом України від 05.09.2017 № 2145-VIII. URL: https://zakon.rada.gov.ua/laws/show/5499-17.

${ }^{10}$ Национальная система учета кадровых ресурсов здравоохранения. Пособие по внедрению URL: http://www.who.int/hrh/documents/brief_nhwa_imp-guide/en.

11 Diallo K. Data on the migration of health-care workers: sources, uses, and challenges. Bulletin of the World Health Organization. 2004. №82. C. 559-636. 
do not solve qualified specialists out flow problem (for example, $20 \%$ of dentists who are officially working in Poland come from Ukraine).

There is a still a question about what kind of specialists do we need and in what quantity? There for, in the process of medical reform the state order for training and education specialists and their redistribution must be based on objective factual data of human resources of the country in particular and in its separate regions. However, in different countries, the approaches to specialization of medical staff, his responsibility is classified in different ways, and that complicates comparative analysis. The nomenclature of health care specialties in European countries count 53 units, but in Ukraine there is a tendency to increase this number: 123 specialties in 2011, 124 in 2019. In particular, the Decree of the Ministry of Health of Ukraine (February 22, 2019 No. 446) "Some issues of continuous professional development of doctors" approved nomenclature of medical specialties including 124 specialties: 1) general medicine - 17 specialties; 2) surgery 18 specialties; 3) pediatrics - 25 specialties; 4) dentistry - 6 specialties; 5) other - 58 specialties. And by the way, medical specialists with higher education is much wider concept than the doctors who provide direct medical care to patients, but the number of who is also used to describe the human resources situation in the healthcare industry.

At the same time, in the conditions of modern transformation of the industry there is a significant disproportion of specialists in different fields, among which some are very fashionable and some of the mare not really popular. And that complicates the distribution of the medical staff equability and creates a number of new problems. Among the most common is the availability of certain types of medical care to the rural population; uncertainty correlation between primary and specialized health-workforce in accordance with international standards; the uncertain role of a highly specialized doctors in the transformed health care system

According to the results of the analysis of the health system staff resources in the Transcarpathian region, the proportion of specialized medical care physicians (SMC) on 01.01.2019 year was 80.6\%, primary health care physicians (PMC) - 15.9\% and emergency medical care (EMC) is $3.5 \%$, which almost corresponds to the distribution of workforce by types of medical care in Ukraine (79\%, 18\% and 3\%, respectively). The structure and staffing of the health system by type of medical care has not really changed since 2014. The correlation between primary care physicians (PMC) and secondary care physicians (SMC) in 2018 was 1:5 and in the

${ }^{12}$ Auriol L, Sexton J. Human resources in science and technology:measurement issues and international mobility. In: International mobility of the highly skilled. Paris, Organisation for Economic Co-operation and Development. 2002. C. 13-39. 
dynamics for 2014-2018 has been almost the same (1:5.4 in 2014). At the same time it does not match the same ratio in the European Union, where the corresponding index is 1:3.

Directly specialized medical care in the Transcarpathian region in 2018 was provided by 3553 physicians (physical persons). For staff provision analysis for specialized medical care experts were divided according to their specialization into 6 professional groups: therapeutic, surgical, obstetric, pediatric, diagnostic and other specialties. The group of other specialties include following physicians (oncologists, neurologists, dentists, geneticists, epidemiologists, otolaryngologists, psychologists, psychiatrists and others).

The biggest group of specialists (physical persons) is the group called others (36,0\%), then therapeutic group (32,4\%) and surgical group (12,4\%). Such structure distribution is common since 2014. At the same time in the dynamics 2014-2018 there is gradual decrease of quantity of doctors in each professional group, except therapeutic (the quantity of doctors in which while the period of study has increased from 1117 to 1152 persons (+3,1\%) (Table 1)

Table 1

The Structure of specialized medical care staff provision

by groups of specialties of the health care system

in Trascarpathian region (2014-2018)

\begin{tabular}{|c|c|c|c|c|c|c|c|c|c|c|}
\hline \multirow{3}{*}{\begin{tabular}{|c|} 
Physical \\
persons at \\
the \\
institutions \\
in general \\
\end{tabular}} & \multicolumn{10}{|c|}{ Years } \\
\hline & \multicolumn{2}{|c|}{2014} & \multicolumn{2}{|c|}{2015} & \multicolumn{2}{|c|}{2016} & \multicolumn{2}{|c|}{2017} & \multicolumn{2}{|c|}{2018} \\
\hline & abs. & $\%$ & abs. & $\%$ & abs. & $\%$ & abs. & $\%$ & abs. & $\%$ \\
\hline $\begin{array}{|lr|}\text { Doctors in } \\
\text { general }\end{array}$ & 3803 & 100,0 & 3865 & 100,0 & 3790 & 100,0 & 3683 & 100,0 & 3553 & 100,0 \\
\hline $\begin{array}{l}\text { Therapeutic } \\
\text { group }\end{array}$ & 1117 & 29,4 & 1162 & 30,0 & 1176 & 31,1 & 1133 & 30,8 & 1152 & 32,4 \\
\hline \begin{tabular}{|l|}
$\begin{array}{l}\text { Surgical } \\
\text { group }\end{array}$ \\
\end{tabular} & 459 & 12,1 & 455 & 11,8 & 448 & 11,8 & 436 & 11,8 & 438 & 12,4 \\
\hline $\begin{array}{l}\text { Obstetric } \\
\text { and } \\
\text { Gynecology } \\
\text { group } \\
\end{array}$ & 254 & 6,7 & 261 & 6,8 & 255 & 6,7 & 255 & 6,9 & 245 & 6,9 \\
\hline \begin{tabular}{|l|} 
Pediatric \\
group
\end{tabular} & 196 & 5,2 & 203 & 5,3 & 164 & 4,3 & 160 & 4,3 & 152 & 4,3 \\
\hline \begin{tabular}{|l} 
Diagnostic \\
group
\end{tabular} & 298 & 7,8 & 296 & 7,7 & 292 & 7,7 & 290 & 7,9 & 286 & 8,0 \\
\hline Others & 1479 & 38,8 & 1488 & 38,4 & 1455 & 38,4 & 1409 & 38,3 & 1280 & 36,0 \\
\hline
\end{tabular}


Listed in table.1 information tells about the increase of the share of physicians in the therapeutic group by $3.0 \%$ and a decrease of $0.9 \%$ of the share of physicians in the pediatric group with the largest share $(36.0 \%)$ of physicians belonging to the group of others in the dynamics 2014-2018.

Provision of doctors providing specialized medical care for the population of the region in 2018 is 31.07 per 10 thousand populations, with individuals - 28.3, respectively. Among the represented professional groups, the largest indicator of the provision for the population in Transcarpathian region with both full-time positions and individuals was in the therapeutic group and the group of other specialists -10.43 and 9.18 per 10 thousand population and 9.18 and 9.04 per 10 thousand persons respectively.

The provision analysis of the population of the region with specialists during the period of study (2014-2018) shows different trends of indicators in different groups (Table 2).

Table 2

Population provision dynamics in Transcarpathian region with doctors providing specialized medical care (2014-2018, per 10 thousand populations)

\begin{tabular}{|c|c|c|c|c|c|c|c|c|}
\hline \multirow[b]{2}{*}{ Years } & \multirow[b]{2}{*}{$\begin{array}{l}\text { Provision } \\
\text { indicator }\end{array}$} & \multicolumn{7}{|c|}{ Professional groups } \\
\hline & & 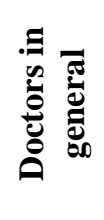 & & 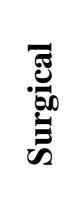 & 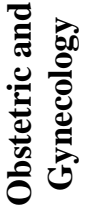 & . & 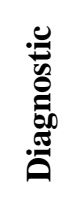 & 离 \\
\hline \multirow[t]{2}{*}{2014} & $\begin{array}{l}\text { Full-time } \\
\text { positions }\end{array}$ & 31,47 & 9,65 & 3,90 & 1,76 & 1,69 & 3,12 & 9,59 \\
\hline & Individuals & 30,33 & 8,91 & 3,66 & 2,03 & 1,56 & 2,38 & 10,14 \\
\hline \multirow[t]{2}{*}{2015} & $\begin{array}{l}\text { Full-time } \\
\text { positions }\end{array}$ & 31,94 & 9,85 & 3,95 & 1,78 & 1,75 & 3,21 & 9,63 \\
\hline & Individuals & 30,75 & 9,25 & 3,62 & 2,08 & 1,62 & 2,36 & 10,21 \\
\hline \multirow[t]{2}{*}{2016} & $\begin{array}{l}\text { Full-time } \\
\text { positions }\end{array}$ & 31,77 & 10,12 & 4,03 & 1,74 & 1,41 & 3,20 & 9,65 \\
\hline & Individuals & 30,17 & 9,36 & 3,57 & 2,03 & 1,31 & 2,32 & 10,06 \\
\hline \multirow[t]{2}{*}{2017} & $\begin{array}{l}\text { Full-time } \\
\text { positions }\end{array}$ & 31,61 & 10,13 & 4,02 & 1,77 & 1,42 & 3,19 & 9,45 \\
\hline & Individuals & 29,32 & 9,02 & 3,47 & 2,03 & 1,27 & 2,31 & 9,70 \\
\hline 2018 & $\begin{array}{l}\text { Full-time } \\
\text { positions }\end{array}$ & 31,07 & 10,43 & 3,98 & 1,74 & 1,35 & 3,10 & 9,18 \\
\hline
\end{tabular}




\begin{tabular}{|l|l|l|l|l|l|l|l|} 
Individuals & 28,30 & 9,18 & 3,49 & 1,95 & 1,21 & 2,28 & 9,04 \\
\hline
\end{tabular}

So during the study period, medical specialists positions provision for the population has not statistically significantly changed (31,47 per 10 thousand population in 2014 and 31,07 in 2018, respectively), but during 20142018 the level of staff provision was reduced from $95.2 \%$ to $92,0 \%$. This situation shows not only the shortage of health-workforce in the region, but also its gradual increase.

Providing full-time positions for doctors in 2018 in different groups varies strongly: in the therapeutic it is $88.0 \%$, in surgical $-87,0 \%$, in obstetric - $112,0 \%$, in pediatric - $89,6 \%$, in diagnostic $73.5 \%$, other specialty $-98.5 \%$. It should be also mentioned that the dynamics during the analyzed five years says that the provision of doctors in all groups decreases, and most significantly in the group of other professionals (7.2\%), surgical (6.7\%) and therapeutic (4.3\%). Thus, taking in account the existing shortage of staff and because of the geography of Transcarpathian region (four borders with other countries), we assume the impact of external migration on the decrease the coverage level of doctors proving health care for the population.

In General, the number of established positions for medical specialists in hospitals has a tendency to decrease from 3946,5 in 2014 to 3587,8 in 2018 (9.1\%). In this case, the difference between the nominal and occupied positions in 2018 is 312,5 that reveals the existing problem of staff shortage. These trend indicators are typical in general and in Ukraine, where this indicator decreased by $11.1 \%$.

In the context of individual occupational groups, the number of established positions for doctors in the dynamics during the analyzed five years has increased at the expense of physicians (8.2\%) and surgeons $(2.4 \%)$. But the provision of the positions for doctors in other professional groups is gradually decreasing, which is typical for Ukraine and for other countries in general (table 3).

As we can see from the results of the study the largest rate of decrease in the number of full-time positions for doctors during this period is typical for the pediatric group (-20.1\%), and this decrease is almost twice the rate of decrease in full-time positions for doctors in this group in Ukraine (-12.4\%). However, the largest shortage of staff is more typical for the therapeutic group $(11.4 \%)$. Thus, with a general shortage of staff providing specialized medical care in $8.7 \%$, in pediatrics group it reaches $10.4 \%$, in diagnostic $8.7 \%$, in the group of other specialties $-7.8 \%$, in the surgical group $-6.8 \%$, and in obstetrics and gynecology $-4.0 \%$.

At the end of 2018, the staffing rate of doctors providing specialized medical care was $92.0 \%$, and in all groups divided the specialty it exceeded 
the corresponding indicators in Ukraine and was enough good for the standards for providing quality medical care (at least 75\%).

Table3

Dynamics of the number of full-time and employed positions of doctors in certain professional groups (Trascarpathian region, 2014-2018)

\begin{tabular}{|c|c|c|c|c|c|c|c|c|}
\hline \multirow[b]{2}{*}{ 总 } & \multirow[b]{2}{*}{ Positions } & \multicolumn{7}{|c|}{ Professional groups } \\
\hline & & 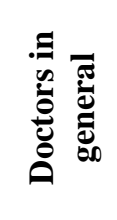 & & 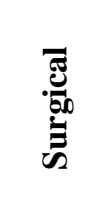 & 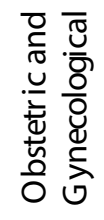 & لِّ & 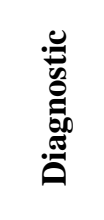 & (ّ) \\
\hline \multirow{2}{*}{$\stackrel{\nabla}{\stackrel{\nabla}{\sim}}$} & $\begin{array}{l}\text { Full-time } \\
\text { positions }\end{array}$ & 3946,5 & 1210,5 & 488,5 & 220,3 & 212,5 & 390,8 & 1263,3 \\
\hline & $\begin{array}{l}\text { Occupied } \\
\text { positions }\end{array}$ & 3756,3 & 1138 & 464,3 & 216,5 & 198,8 & 377,3 & 1206,3 \\
\hline \multirow{2}{*}{$\stackrel{\text { 뭉 }}{\circ}$} & $\begin{array}{l}\text { Full-time } \\
\text { positions }\end{array}$ & 4013,8 & 1237,5 & 496,3 & 223,3 & 219,8 & 404 & 1268,8 \\
\hline & $\begin{array}{l}\text { Occupied } \\
\text { positions }\end{array}$ & 3827,3 & 1177,5 & 469,5 & 219,8 & 207,5 & 386,3 & 1212,3 \\
\hline \multirow{2}{*}{$\begin{array}{l}0 \\
\stackrel{0}{2}\end{array}$} & $\begin{array}{l}\text { Full-time } \\
\text { positions }\end{array}$ & 3991 & 1271,3 & 506,5 & 218,8 & 177,3 & 402,5 & 1270,3 \\
\hline & $\begin{array}{l}\text { Occupied } \\
\text { positions }\end{array}$ & 3768,5 & 1191,3 & 471,8 & 217,3 & 166,3 & 379 & 1204,5 \\
\hline \multirow{2}{*}{ 혹 } & \begin{tabular}{|l|} 
Full-time \\
positions
\end{tabular} & 3970,3 & 1272,5 & 504,5 & 222,8 & 178 & 401,3 & 1247,0 \\
\hline & $\begin{array}{l}\text { Occupied } \\
\text { positions }\end{array}$ & 3706,8 & 1172 & 471,3 & 216,3 & 163 & 374,5 & 1168,5 \\
\hline \multirow{2}{*}{$\stackrel{\infty}{\stackrel{\infty}{\circ}}$} & $\begin{array}{l}\text { Full-time } \\
\text { positions }\end{array}$ & 3900,3 & 1309,5 & 500 & 219 & 169,8 & 388,8 & 1214,8 \\
\hline & $\begin{array}{l}\text { Occupied } \\
\text { positions }\end{array}$ & 3587,8 & 1175,5 & 468 & 210,5 & 154,3 & 357,8 & 1126,8 \\
\hline
\end{tabular}

In the dynamics 2014-2018, the staffing indicator decreased from 95.2\% to $92.0 \%$, which corresponds to the trend of the indicator in Ukraine (Fig. 1).

The staffing rate for doctors in certain professional groups during the study period 2014-2018 in the Transcarpathian region also tended to decrease. Moreover, the decreases in the diagnostic and therapeutic groups were the most significant (Fig. 2).

The staffing rate of specialized medical care specialists, taking into account part-time job in 2018 was 100\%, as in other professional groups: therapeutic $-102 \%$, surgical $-106.8 \%$, pediatric $-101.5 \%$, diagnostic - 
$125 \%$. The exception is the obstetrics and gynecology group where the staffing of doctors by individuals is $85.9 \%$.

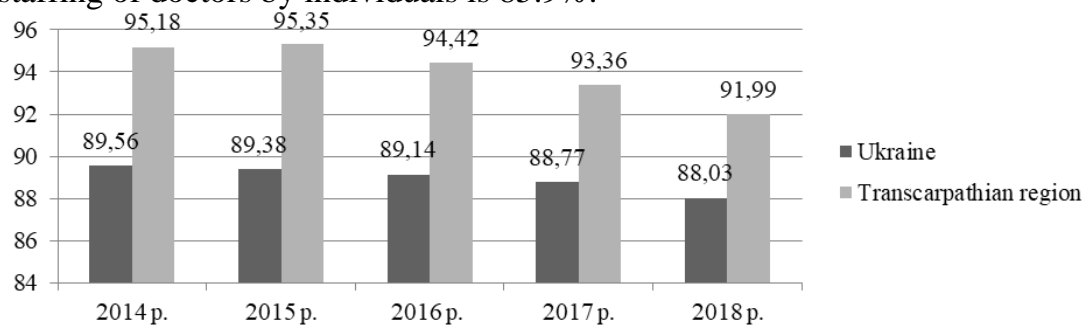

Fig. 1. Dynamics of the staffing rate of doctors

providing specialized medical care in the health care system

of Transcarpathian region and Ukraine (2014-2018)

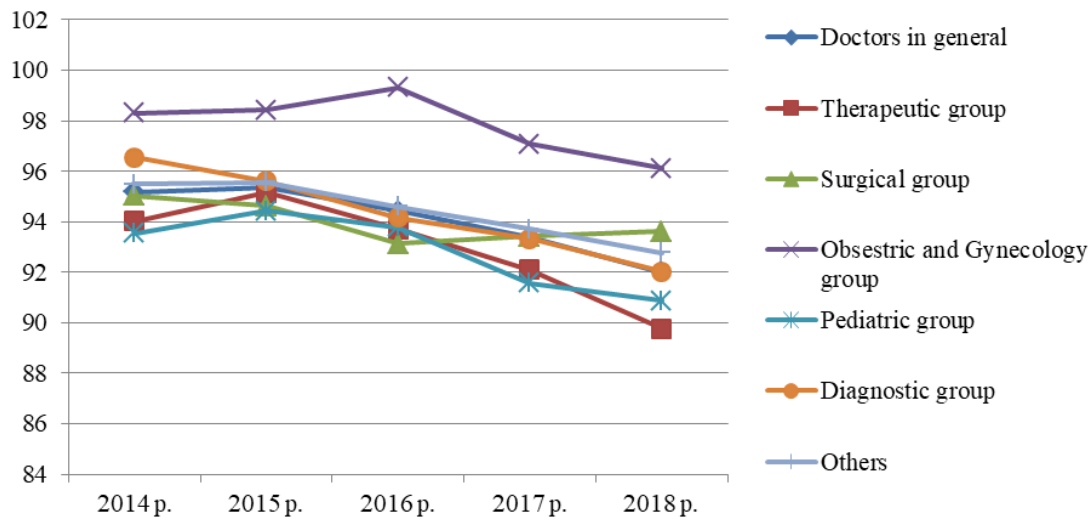

Fig. 2. Dynamics of the staffing rate of doctors in certain professional groups of the health care system in the Transcarpathian region (2014-2018)

If we look at the human resources in the Transcarpathian region in terms of individual biogeochemical zones (lowland, foothills and mountains), which differ in demographic characteristics, geochemical characteristics and socio-economic factors, it turns out that at the end of 2018 the problem of shortage of medical staff is found in all zones. At the same time, the number of vacant positions for specialists is the largest in the lowlands, but the staffing rate is still more than $90 \%$, as it is in other areas (Table 4).

However, the indicator of the provision of individuals with specialists in the mountain zone is the lowest $(88.3 \%$ against $97.3 \%$ in the foothills and 91.3 - in the lowlands), which must be taken into account when developing workforce policy in the region.

Thus, the presence of a shortage of medical staff that provides specialized medical care in the region, and a greater rate staffing reduction of 
these specialists in certain professional groups compared to Ukraine, in our opinion, indicates the impact of internal and / or external migration of health care sector workers in the Transcarpathian region.

Table 4

Personnel potential of the health care system in the Transcarpathian region in 2018 in terms of individual biogeochemical zones

\begin{tabular}{|c|c|c|c|c|c|c|}
\hline \multirow[b]{2}{*}{$\begin{array}{l}\text { Biogeoche } \\
\text { mical zone }\end{array}$} & \multicolumn{2}{|c|}{$\begin{array}{c}\begin{array}{c}\text { Positions } \\
\text { of doctors, abs. }\end{array} \\
\end{array}$} & \multirow{2}{*}{ 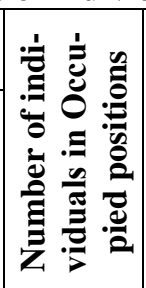 } & \multirow[b]{2}{*}{ 苞 } & \multirow{2}{*}{ 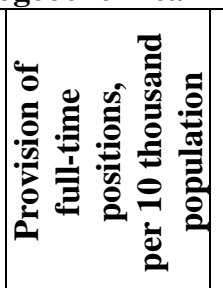 } & \multirow{2}{*}{ 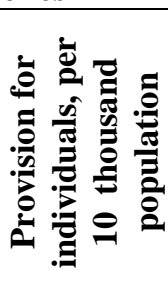 } \\
\hline & 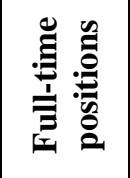 & 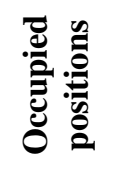 & & & & \\
\hline \begin{tabular}{|l|}
$\begin{array}{l}\text { Lowland } \\
\text { area }\end{array}$ \\
\end{tabular} & 1090,25 & 984,75 & 996,00 & 90,32 & 8,69 & 7,93 \\
\hline Foothill area & 990,75 & 905,25 & 964,00 & 91,37 & 7,89 & 7,68 \\
\hline $\begin{array}{l}\text { Mountain } \\
\text { area }\end{array}$ & 332,00 & 307,00 & 292,00 & 92,47 & 2,64 & 2,33 \\
\hline
\end{tabular}

The intra-industry structure of specialized medical care staffing in 2018 differed significantly by the of doctors' place of work. Thus, from the total number of medical positions, $57.2 \%$ of positions are provided in outpatient clinics and $42.8 \%$ - in hospitals, of which $56.3 \%$ and $43.7 \%$ are employed, respectively. The largest number of positions held in outpatient clinics is occupied by physicians of the therapeutic group (79.6\%). Instead, the largest number of positions in hospitals belongs to doctors of the surgical group (82.9\%) and pediatric group $(74.1 \%)$. At the same time, the number of positions of doctors of obstetrics and gynecology group that provide outpatient and inpatient care is almost the same (51.1\% and $48.9 \%)$, and the number of positions of doctors of pediatric and diagnostic groups in hospitals of the region significantly exceeds their number in outpatient clinics (74.1\% and 67.1\%, respectively) (Fig. 3).

The distribution of the number of doctors who provide specialized medical care in outpatient clinics and hospitals in the dynamics of 20142018 in the Transcarpathian region has not really changed, in general and in some professional groups, except pediatric group. Thus, in 2014 43.9\% of pediatricians worked in outpatient clinics, but by 2018 their number decreased by 1.7 times and amounted to $25.9 \%$.

At the same time, it should be noted that in 2018 in all groups of doctors in certain specialties there are vacancies, as evidenced by the difference 
between full-time and occupied positions as a whole in the region and separately in outpatient and inpatient health care facilities (Table 5).

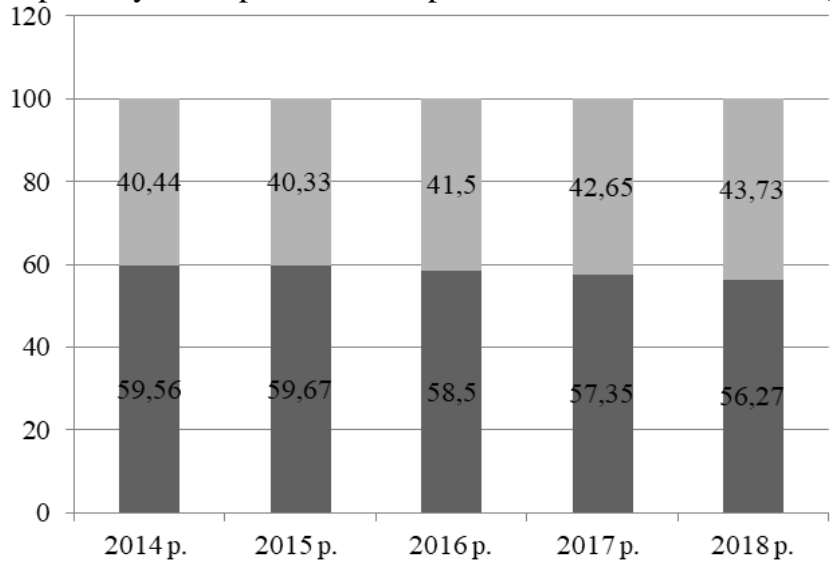

Inpatient clinic

- Outpatient clinic

Fig. 3. Intra-branch structure of doctors of the health care system in the Transcarpathian region by place of work in the dynamics of 2014-2018

Table 5

Positions of doctors who provide specialized medical care and their employment in outpatient clinics and hospitals in the Transcarpathian region (2018)

\begin{tabular}{|c|c|c|c|c|c|c|c|c|c|}
\hline \multirow[b]{2}{*}{ Group } & \multicolumn{3}{|c|}{$\begin{array}{c}\text { The number of } \\
\text { positions in the whole } \\
\text { institution }\end{array}$} & \multicolumn{3}{|c|}{$\begin{array}{l}\text { Of these, in } \\
\text { outpatient clinics }\end{array}$} & \multicolumn{3}{|c|}{$\begin{array}{l}\text { Of them in the } \\
\text { hospital }\end{array}$} \\
\hline & 产 & 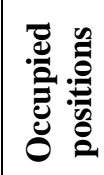 & 莺 & 莺 & 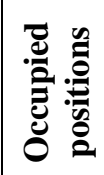 & 莺 & 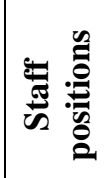 & 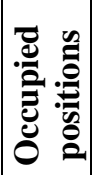 & 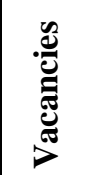 \\
\hline $\begin{array}{l}\text { Doctors in } \\
\text { general }\end{array}$ & 3900,3 & 3587,8 & 312,5 & 2229 & 2018,8 & 210,1 & 1671,3 & 1569 & 102,3 \\
\hline $\begin{array}{l}\text { Therapeutic } \\
\text { group }\end{array}$ & 1309,5 & 1175,5 & 134 & 1055 & 935,8 & 119,3 & 254,5 & 239,8 & 14,8 \\
\hline \begin{tabular}{|l|}
$\begin{array}{l}\text { Surgical } \\
\text { group }\end{array}$ \\
\end{tabular} & 500 & 468 & 32 & 88,3 & 80 & 8,3 & 411,8 & 388 & 23,8 \\
\hline $\begin{array}{l}\text { Obstetric \& } \\
\text { Gynecolo- } \\
\text { gical group }\end{array}$ & 219 & 210,5 & 8,5 & 110,8 & 107,5 & 3,3 & 108,3 & 103 & 5,3 \\
\hline \begin{tabular}{|l|} 
Pediatric \\
group
\end{tabular} & 169,8 & 154,3 & 15,5 & 48,5 & 40 & 8,5 & 121,3 & 114,3 & 7 \\
\hline
\end{tabular}




\begin{tabular}{|l|c|c|c|c|c|c|c|c|c|}
\hline $\begin{array}{l}\text { Diagnostic } \\
\text { group }\end{array}$ & 388,8 & 357,8 & 31 & 130,8 & 118 & 12,8 & 258 & 239,8 & 18,3 \\
\hline
\end{tabular}

The number of vacancies for specialist doctors in the CHI's in general is 312.5 full-time units, mostly in outpatient clinics (210.1 vs. 102.3). The largest number of vacancies in general is more typical for the therapeutic group (134 full-time units), as well mostly in outpatient clinics 119.3 full-time units. Instead, in hospitals it is more observed in the surgical group (23.8 full-time units).

As for the secondary level of medical care in general, and taking into account the intra-sectoral structure of doctors in health care system, this situation indicates a shortage of staff, and the reasons needs further study accounting the demographic and geographical characteristics of the Transcarpathian region. Monitoring the human resources potential of the region in the dynamics can be an informative tool for the regional workforce policy development in the context of modern medical reform.

\section{CONCLUSIONS}

The results of analysis in the Transcarpathian region allows to establish that in 2018 the share of doctors providing specialized medical care reaches $80.6 \%$, which in relation to the share of primary care physicians is $1: 5$ and does not correspond to the corresponding ratio in the countries of the European Union where this index 1: 3. The largest share of specialists is represented by specialists from the professional group of other specialists (36.0\%), the smallest - by the pediatric group (4.3). At the same time, in the dynamics for 2014-2018, a decrease in the share of doctors was found only in the pediatric group (0.9\%).

It is established that the rate of doctors providing specialized medical care in 2018 is 31,07 per 10 thousand populations (individuals doctors 28.3, respectively). Among the various professional groups, the highest level of provision is for physicians - to 10.43 per 10 thousand populations (individuals of doctors -9.18 , respectively).

It is proved that during 2014-2018 full-time positions of medical specialists in the Transcarpathian region declined by 3.2\%, in particular due to the diagnostic (4.6\%) and therapeutic groups (4.3\%) and in 2018, it is $92.0 \%$ (Ukraine $-88,0 \%$ ). In this case, the smallest positions staffing of individuals appears in the diagnostic group (73.5\%), but the reduction in positions staffing of individual doctors the most significant is due to the professional group called other professionals (7.2\%). Accounting the parttime and full-time positions of medical specialists in 2018 the level is 100\% in all occupational groups, except obstetric and gynecological (85,9\%).

In the dynamics during the study period (2014-2018 years) number of full-time posts of medical specialists decreased by $9.1 \%$ and corresponds to 
tendency in Ukraine in general, in particular, due to the pediatric group $(-20,1 \%)$. At the same time, the shortage of health-workforce in the Transcarpathian region in 2018 amounted 8.7\%, mostly due to the therapeutic group (11.4\%).

In the context of individual biogeochemical zones of Transcarpathian region in 2018, a shortage of doctors was identified in all zones of the region, thus, a measure of full-time positions staffing of medical specialists in each area exceeds $90.0 \%$. However, staffing of individuals of doctors positions is lowest in the mountain zone $(88,3 \%)$.

While studying the intra-industry structure of the health care system with specialized medical care staffing, it was found that in 2018 the ratio between the number of positions of doctors in outpatient clinics and hospitals is 1: 1.3. At the same time, the largest numbers of positions in outpatient clinics are occupied by physicians (79.6\%), in hospitals - by surgeons (82.9\%).

In the dynamics for 2014-2018 there is a significant decrease in the number of pediatricians working in outpatient clinics in the region (1.7 times). At the same time, all professional groups have vacancies, regardless of the place of work. The current shortage of specialized medical care, in our opinion, indicates the possible impact of migration on its level.

Given the current shortage of staff and demographic and geographical features of the Transcarpathian region, the risks of losing health workers due to external migration may increase in the future, which may slow down the process of medical reform. Therefore, monitoring the human resources of the region in the dynamics can be one of the levers for the implementation of effective staff (workforce) policy in accordance with the objectives and mechanisms of the reform, taking into account regional specifics.

\section{SUMMARY}

Analysis of staffing of the health system in the Transcarpathian region with specialized medical care, both in General and specific occupational groups of professionals, has allowed us to establish that in 2018 the proportion of doctors providing specialized medical care reaches $80.6 \%$ (1:5 in relation to the proportion of primary care physicians) that does not match the corresponding ratio in the European Union 1:3. The rate of population provision in Transcarpathian region by medical specialists is 31,07 per 10 thousand population (individuals doctors and 28.3, respectively). The ratio between the number of positions in outpatient clinics and hospitals is 1:1,3.

In dynamics during 2014-2018 full-time positions staffing of medical specialists in the Transcarpathian region declined by 3.2\%, in particular due to the diagnostic (4.6\%) and therapeutic groups (4.3\%) and in 2018 it was 92.0\% (Ukraine $-88,0 \%$ ), and the number of medical specialists' positions decreased by $9.1 \%$ (in particular, due to the pediatric group - by $20.1 \%$ ). 
The shortage of staff in the Transcarpathian region in 2018 amounted 8.7\%, just due to the therapeutic group (11.4\%), also there was a significant decrease in the number of pediatricians working in the outpatient clinics of the region indicated (1.7 times).

A shortage of doctors is identified in all zones of the region, but the staffing in each is more than $90.0 \%$; except in the mountain zone (88,3\%).

Taking into account shortage and demographic and geographic features of the Transcarpathian region in the future may increase risks of loss of health workers due to external migration may increase, which may slower the process of health reform in the future.

\section{REFERENCES}

1. Global strategy on human resources for health: workforce 2030. URL: https://www.who.int/hrh/resources/global_strategy_workforce2030_ 14_print.pdf?ua=1.

2. Указ Президента України від 30.09.2019 № 722/2019 «Про Цілі сталого розвитку України на період до 2030 року». URL: https://zakon.rada.gov.ua/laws/show/722/2019.

3. Закон України від 19.10.2017 № 2168-VIII «Про державні фінансові гарантії медичного обслуговування населення». URL: https://zakon.rada.gov.ua/laws/show/2168-19.

4. Устінов О.В. Реформування медичної галузі в Україні отримало законодавче забезпечення №4(84) VII-VIII 2011 г. URL: https://www.umj.com.ua/article/writer/ustinov-a-v.

5. Campbell, J., Buchan, J., Cometto, G., David, B., Dussault, G., Fogstad, H., ... \& Quain, E.E. Human resources for health and universal health coverage: fostering equity and effective coverage. Bulletin of the World Health Organization. 2013. № 91. C. 853-863.

6. Conceptual framework for human resources for health / Global Health Workforce Alliance. URL: https://www.capacityproject.org/ framework/.

7. Надутий К.О., Лехан В.М., Найда І.В. Обгрунтування концепції безперервного вдосконалення національної системи охорони здоров'я України. Украӥнський медичний часопис. 2019. URL: https://doi.org/ 10.32471/umj.1680-3051.129.138238.

8. Закон України «Про формування та розміщення державного замовлення на підготовку фахівців, наукових, науково-педагогічних $\mathrm{i}$ робітничих кадрів, підвищення кваліфікації та перепідготовку кадрів» зі змінами, внесеними згідно із Законом України від 05.09.2017 № 2145-VIII. URL: https://zakon.rada.gov.ua/laws/show/5499-17. 
9. Национальная система учета кадровых ресурсов здравоохранения. Пособие по внедрению URL: http://www.who.int/hrh/ documents/brief_nhwa_imp-guide/en.

10. Богдан Д., Бойко А., Василькова А. та ін. Кадрові ресурси системи охорони здоров'я в Україні. Ситуаційний аналіз. Проект USAID «Підтримка реформи охорони здоров'я» URL: https://www.umj.com.ua/ article/138238/obgruntuvannya-kontseptsiyi-bezperervnogo-vdoskonalennyanatsionalnoyi-sistemi-ohoroni-zdorov-ya-ukrayini.

11. Diallo K. Data on the migration of health-care workers: sources, uses, and challenges. Bulletin of the World Health Organization. 2004. № 82. C. 559-636.

12. Auriol L, Sexton J. Human resources in science and technology: measurement issues and international mobility. In: International mobility of the highly skilled. Paris, Organisation for Economic Co-operation and Development. 2002. C. 13-39.

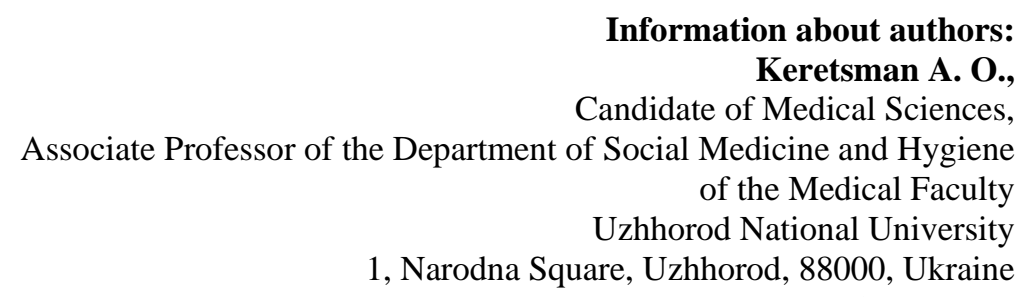

Melnichuk N.I.,

Senior Lecturer of the Department of Dentistry of Postgraduate Education with a Course of Therapeutic and Orthopedic Dentistry Uzhhorod National University 100, Starodomanynska Street, Uzhhorod, 88000, Ukraine 